\title{
SAMORZĄD TERYTORIALNY WOBEC ZASADY PODZIAŁU WŁADZY
}

\section{WPROWADZENIE}

Obecnie powszechnie aprobowana jest teza, że samorząd terytorialny jako ustrojowa instytucja prawna i prawnicza stanowi nieodzowny komponent demokratycznego państwa prawnego ${ }^{1}$. W związku z powyższym poglądem rozważyć trzeba zatem, jakie wartości realizuje ta instytucja w polskim porządku prawnym. Z zasadą demokratycznego państwa prawnego wyrażona w art. 2 Konstytucji $\mathrm{RP}^{2}$ doktryna prawa konstytucyjnego wiąże wartości polityczne, ekonomiczne i prawne. W obrębie wartości politycznych, do których przede wszystkim będzie nawiązywał prezentowany tekst, wymieniane sa m.in.: porządek konstytucyjny, demokracja przedstawicielska, podział władzy, pluralizm polityczny, niezależność sądów, sądowy wymiar sprawiedliwości. Jako wartości ekonomiczne wskazywane sa: społeczna gospodarka rynkowa, wolność działalności gospodarczej, swoboda umów. Na wartości prawne składaja się jego określoność, odpowiednia vacatio legis, zakaz wstecznego działania prawa $^{3}$. Z analizy Konstytucji i ustaw ustrojowych ${ }^{4}$ regulujących odpowiednio status gminy, powiatu i samorządu województwa bezsprzecznie wynika, że upodmiotowiony prawnie samorząd terytorialny jest nieodłacznym elementem porządku konstytucyjnego, wykorzystuje w swej konstrukcji mechanizmy demokracji przedstawicielskiej, działa w realiach pluralizmu politycznego, a swoje relacje z organami nadzoru, a także spory prawne, w których potencjalnie może zaistnieć jako osoba prawa publicznego wyposażona w osobowość prawna, opiera na sądowym wymiarze sprawiedliwości.

Przedmiotem niniejszego artykułu sa rozważania dotyczace realizacji przez współczesny polski samorząd terytorialny konstytucyjnej zasady podziału władzy. Stawiam tezę, że podmioty samorządu terytorialnego podmiotowo, przedmiotowo (w sferze zadań publicznych) i funkcjonalnie (kompetencyjnie)

${ }^{1}$ Zob. preambuła do Europejskiej karty samorządu lokalnego sporządzonej w Strasburgu dnia 15 października 1985 r., Dz. U. 1994, Nr 124, poz. 607.

${ }^{2}$ Konstytucja Rzeczypospolitej Polskiej z 2 kwietnia 1997 r., Dz. U. 1997, Nr 78, poz. 483 (dalej jako: Konstytucja).

${ }^{3}$ Florczak-Wator (2019): 25-26.

${ }^{4}$ Zob.: ustawa z 8 marca 1990 r. o samorządzie gminnym, t.jedn.: Dz. U. 2020, poz. 713; ustawa z 5 czerwca 1998 r. o samorządzie powiatowym, t.jedn.: Dz. U. 2020, poz. 920; ustawa z 5 czerwca 1998 r. o samorządzie województwa, t.jedn.: Dz. U. 2019, poz. 512. 
wskutek swego bytu prawnego „dzielą” władzę wykonawczą w szerokim tego słowa ${ }^{5}$ znaczeniu, nawiązującym do pojęcia organów administracyjnych i administrujacych. W związku z tym relacje pomiędzy podmiotami tej właśnie władzy (wykonawczej) w takim szerokim ujęciu powinno się badać także według kryterium wzajemnego równoważenia się i odpowiednio hamowania i współdziałania tych podmiotów. Jednocześnie z uwagi na korporacyjną strukturę ustroju i organizacji podmiotów samorządu terytorialnego istotna jest kwestia podziału i równoważenia władzy w jego budowie wewnętrznej w powiązaniu z funkcjonowaniem na zewnątrz. Zarazem - z uwagi na wymogi demokratyzacji życia społecznego - istotna przede wszystkim jest pozycja człowieka, jednostki wobec samorządu terytorialnego i w samorządzie terytorialnym.

Zaprezentowane refleksje zostały zainspirowane poglądami Ryszarda M. Małajnego, który postrzegając i analizując stanowiska kontestujące przydatność zasady podziału władzy, w sposób otwarty ją scharakteryzował, że „zasadniczą treść idei rozdziału władzy państwowej determinują następujące kanony: a) podział prawnych sfer działania państwa; b) stosownie do podziału powyższych sfer - dokonanie rozdziału aparatu państwowego na odpowiadające im grupy organów (minimum dwie); c) stosunki między tymi organami opierają się na zasadzie niezależności i równorzędności; d) poszczególne grupy organów wzajemnie się hamuja, przy czym to hamowanie się skutkuje zarówno ich względna równowaga, jak i współpraca; e) każda grupa organów realizuje przede wszystkim swą własną prawną sferę działania oraz dysponuje stosunkowo ograniczoną możliwością ingerencji w działalność pozostałych

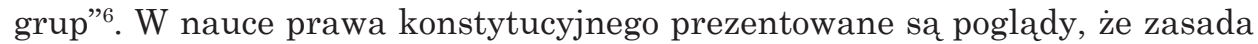
podziału władzy odnosi się tylko do organów naczelnych ${ }^{7}$. Także w orzeczeniu Trybunału Konstytucyjnego z 23 października 1995 r. (K 4/95) przyjęto, że zasada podziału władzy nie ma zastosowania do samorządu terytorialnego. W przypadku tego ostatniego poglądu w mojej ocenie stanowisko to przede wszystkim dotyczy oczywistej konstatacji, że natura związkowa jednostek samorządu terytorialnego i posiadanie przez nie organów stanowiących i wykonawczych nie są wyrazem ustrojowej zasady podziału władzy, tylko ustrojowo-organizacyjną formą podziału władzy wykonawczej.

Podzielam poglądy podnoszące, że Konstytucja wprowadziła nie tylko poziomy podział władzy pomiędzy naczelne organy państwa, lecz także podział pionowy tej władzy, którego przejawem jest byt podmiotów samorządu terytorialnego ${ }^{8}$. Moim zdaniem podział pionowy władzy determinowany zarazem zasada decentralizacji jest instrumentalny prawnie wobec poziomego i nie podzielam tez, według których jest to podział niezależny, separowany od zasady podziału władzy.

W mojej ocenie warto określić miejsce samorządu terytorialnego z perspektywy podziału władzy wykonawczej i w nawiązaniu do zasady podziału władzy

${ }^{5} \mathrm{Na}$ temat pojęcia władzy wykonawczej w szerokim znaczeniu szerzej: Skrzydło-Niżnik (2000): 78-80. Zob. także Skrzydło-Niżnik (2007): 295-297.

${ }_{6}$ Małajny (2009).

7 Pułło (1993): 11.

8 Taras (2005): 216. 
z uwagi na znaczenie, jakie mogą mieć te ustalenia dla koncepcji wielopoziomowego rządzenia w Unii Europejskiej. Ustrój organów i instytucji UE nie opiera się na zasadzie podziału władzy, lecz na podziale instytucjonalnym ${ }^{9}$, a także pionowym i poziomym otwarciu się porządków prawnych państw członkowskich na porządek prawa europejskiego ${ }^{10}$. Jednocześnie w zakresie tworzenia i wykonywania prawa europejskiego jest widoczne wyżej wspomniane wielopoziomowe rządzenie ${ }^{11}$. W tym wielopoziomowym rządzeniu na poziomie prawa krajowego jest jednak odpowiednio wpisana zasada podziału władzy. W tym wielopoziomowym rządzeniu swoje istotne miejsce, wskutek zdecentralizowanego wykonywania prawa administracyjnego, znajdują także podmioty samorządu terytorialnego (regionalne, ponadlokalne, lokalne) ${ }^{12}$.

\section{SAMORZĄD TERYTORIALNY JAKO INSTYTUCJA REALIZUJĄCA ZASADĘ PODZIAŁU WŁADZY}

Z punktu widzenia istoty samorządu terytorialnego rzeczą naturalną wydaje się jego ocena z perspektywy zasady podziału władzy publicznej. Bezsprzecznie w ujęciu teoretycznym nawiązującym do teorii państwowej wielopodmiotowej samorząd terytorialny określa relacje pomiędzy państwem a tworzonymi przez nie innymi niż ono związkami publicznoprawnymi dla celów administrowania sprawami publicznymi terytorialnymi, lokalnymi, regionalnymi, związanymi z zaspokajaniem potrzeb wspólnot terytorialnych ${ }^{13}$. W teorii państwowej wielopodmiotowej samorządu terytorialnego obecnie aktualnej relacje te opierają się na ograniczonej prawem samodzielności wobec państwa i jego organów tych związków publicznoprawnych, wyodrębnionych według kryterium „lokalnego" terytorium w zakresie administrowania publicznego określonymi przez prawo sprawami lokalnymi ${ }^{14}$. Podmioty samorządu terytorialnego maja publiczne prawo podmiotowe do administrowania i zarządzania wskazanymi prawem sprawami publicznymi terytorialnymi, a instytucja państwa i jego organy mają prawo do nadzorowania, czy to ad-

9 Grzeszczak (2016): 203.

10 Supernat (2013): 19-20.

11 Grzeszczak (2016): 02-203.

12 Por. Jakubek-Lalik (2016): 72-73. Zob. też: Kiczka (2013): 178-179.

13 Bigo (1932): 107-108.

14 Teoria państwowa warunkuje prawny byt podmiotów samorządu terytorialnego od woli suwerena i ustawodawcy. Istnieją w niej różnice pomiędzy teorią państwową jednopodmiotowa a państwową wielopodmiotową. Pierwsza podnosi, że państwo stanowi jedyny podmiot prawa publicznego, jedyny podmiot administracji publicznej i jedyny podmiot samorządu terytorialnego. W tym ujęciu samorząd terytorialny stanowi zdecentralizowany organ państwa nieposiadajacy pełnego kompletu cech osoby prawa publicznego, którymi są struktura związkowa, posiadanie władztwa administracyjnego i osobowości prawnej. Zob. Panejko (1926): 86-90. Teoria wielopodmiotowa wskazuje, że państwo stanowi zasadniczy pierwotny podmiot prawa publicznego, jednak „obok” państwa porządek prawny dopuszcza tworzenie innych niż państwo podmiotów prawa publicznego i w tym podmiotów samorządu terytorialnego. Zob. Bigo (1928): 150-155, a także Kasznica (1946): 63. 
ministrowanie i zarządzanie odbywa się $\mathrm{w}$ ramach prawa ${ }^{15}$. Wprowadzenie do ustroju administracji publicznej instytucji samorządu terytorialnego wprowadza zarazem pewną dychotomię, polegająca na tym, że w „terenie” działaja zarówno scentralizowane terenowe organy administracji rządowej, jak i zdecentralizowane podmioty samorządu terytorialnego. Wszystko zależy zatem od tego, czy suweren dostrzega zakres spraw publicznych kwalifikowanych do względnie samodzielnego administrowania przez upodmiotowione prawnie wspólnoty.

Trzeba zatem zauważyć, że byt prawny samorządu terytorialnego uzasadniaja zadania publiczne z pierwiastkiem interesu lokalnego, które prawnie i faktycznie komponuja się z ich wykonywaniem przez względnie samodzielne lokalne i ponadlokalne podmioty administracji publicznej, którymi sa m.in. jednostki samorządu terytorialnego ${ }^{16}$. W nauce prawa jest mowa o granicy decentralizacji administracji publicznej, która polega na tym, że nie każde zadanie z zakresu administracji publicznej nadaje się w państwie jednolitym do decentralizacji, gdyż zasadniczo nie podlegaja jej zadania publiczne, od których realizacji zależy wprost, bezpośrednio dobro, bezpieczeństwo, sprawne funkcjonowanie całego państwa (inaczej ochrona ogólnych interesów państwa lub ochrona ogólnych interesów innych organów publicznych $)^{17}$. Z Konstytucji i ustaw wynika jedynie istota zadań publicznych tzw. „własnych”, dla których w pierwszej kolejności tworzony jest samorząd terytorialny, a także domniemanie, iż samorząd terytorialny wykonuje zadania publiczne niezastrzeżone przez Konstytucję lub ustawy dla organów innych władz publicznych. Prawny ustawowy podział zadań publicznych pomiędzy administrację państwowa, rządową i samorządowa powinien uwzględniać istotę bytu tych administracji, przy czym trzeba zauważyć, że ze względu na dynamikę stosunków społecznych, europejskie i globalne uwarunkowania władzy państwa - ustawowy podział czy też przydział tych zadań może się zmieniać. Pojawia się wtedy zjawisko recentralizacji zadań publicznych i administracji publicznej, która jest dopuszczalna wtedy, kiedy jest prawnie uzasadniona stawianiem akcentu przy ich wykonaniu przede wszystkim na dobro ogółu, państwa. Niezależnie od tego, jeżeli wynika to z uzasadnionych potrzeb państwa, ustawa może zlecić jednostkom samorządu terytorialnego wykonywanie innych zadań publicznych. Ustawa określa tryb przekazywania i sposób wykonywania zadań zleconych (art. 166 ust. 2 Konstytucji). Regulacje te rozwija m.in. art. 8 ustawy o samorządzie gminnym, stanowiąc, że ustawy mogą nakładać na gminę obowiązek wykonywania zadań zleconych z zakresu administracji rządowej, a także z zakresu organizacji przygotowań i przeprowadzenia wyborów powszechnych oraz referendów. Zarazem zadania z zakresu administracji rządowej gmina może wykonywać również na podstawie porozumienia $\mathrm{z}$ organami tej administracji. A zatem instytu-

${ }^{15} \mathrm{Na}$ temat publicznego prawa podmiotowego zob.: Jaworski (1924): 105-106, a także Bigo (1932): 55-62.

${ }^{16}$ Dolnicki (2005): 141.

17 Boć (2003): 61. 
cja samorządu terytorialnego realizuje wartości związane z podziałem władzy m.in. przez prawny podział na jej rzecz zadań publicznych i związanych z nimi kompetencji i odpowiedzialności.

Trzeba w tym miejscu wyjaśnić, jaki jest charakter, ontologia władzy wykonywanej przez samorząd terytorialny. Z konstytucyjnego stwierdzenia zawartego w art. 16 ust. 2 - podnoszącego, że samorząd terytorialny uczestniczy w sprawowaniu władzy publicznej w związku z art. 4 ust. 1 Konstytucji, zgodnie z którym władza zwierzchnia w Rzeczypospolitej Polskiej należy do Narodu - należy wywieść, że samorząd terytorialny uczestniczy w sprawowaniu władzy publicznej przynależnej do Narodu. A zatem suwerenny Naród w ramach demokracji przedstawicielskiej powierza w drodze Konstytucji i ustaw samorządowi terytorialnemu wykonywanie przynależnej sobie jako suwerenowi władzy publicznej w zakresie zaspokajania zbiorowych potrzeb wspólnot samorządowych. Z tego też wynika, że samorząd terytorialny nie wykonuje jakiejśs naturalnie właściwej sobie, z uwagi na swoją istotę, władzy publicznej, ale pewien zakres władzy publicznej (wykonawczej) przynależnej Narodowi. W celu wykonywania tego zakresu władzy samorząd terytorialny został wyposażony w zadania publiczne, kompetencje, majątek publiczny, dochody, osobowość prawna, samodzielność prawną i odpowiedzialność.

W tym miejscu trzeba zauważyć, że zwierzchnia władza Narodu jest podzielona na trzy obszary aktywności państwa przypisane, odpowiednio, władzy ustawodawczej, wykonawczej i sądowniczej. Kształt ustrojowy władzy wykonawczej jest określony w Konstytucji, przy czym jest dookreślany przez ustawodawcę w drodze demokracji przedstawicielskiej. Zgodnie z art. 10 Konstytucji: „1. Ustrój Rzeczypospolitej Polskiej opiera się na podziale i równowadze władzy ustawodawczej, władzy wykonawczej i władzy sądowniczej. 2. Władzę ustawodawczą sprawują Sejm i Senat, władzę wykonawczą Prezydent Rzeczypospolitej Polskiej i Rada Ministrów, a władzę sądowniczą sądy i trybunały". W postaci wassko rozumianej i - co istotne - dualistycznie podzielonej władzy wykonawczej, z konstytucyjnego ustrojowego punktu widzenia, realizuje się wymóg podziału władzy według obszarów aktywności państwa, równoważenia się tych obszarów/ funkcji państwa, a także wewnętrzny podział władzy w obrębie poszczególnych obszarów aktywności. Z analizy kompetencji Prezydenta RP i z konsekwencji terminologicznych aparatury pojęciowej Konstytucji wynika, że jest on organem władzy wykonawczej, nie posiadając atrybutów organu administracyjnego. Można jedynie stwierdzić, że w pewnych zakresach swojego działania jest organem administrujacym. Posiada cały szereg skutecznych instrumentów pozwalających mu oddziaływać na władzę ustawodawcza, wykonawczą i sądownicza. Dogłębna ich prezentacja przekracza ramy prowadzonych rozważań.

Z kolei Rada Ministrów jako organ władzy wykonawczej mieści się zarazem w pojęciu organu administracyjnego, prowadzi politykę wewnętrzna i zagraniczną Rzeczypospolitej Polskiej, przy czym do Rady Ministrów należą sprawy polityki państwa niezastrzeżone dla innych organów państwowych i samorządu terytorialnego. Rada Ministrów kieruje także administracja rządową. Do Rady Ministrów, jako do rządu, należy zatem rządzenie, czego 
przejawem jest prowadzenie wyżej wspomnianej polityki. Rządzenie stanowi podejmowanie działań na podstawie prawa, przy czym prawo jedynie stanowi ramy dla treści aktów rządzenia i nie przesądza treści tych aktów ${ }^{18}$. Akty te powinny być jednak zgodne z zasadami demokratycznego państwa prawnego.

W tym miejscu, aby dokonać pewnego wartościowania działalności i znaczenia władzy wykonawczej, trzeba podkreślić aksjologię podziału władzy, która w pierwszej kolejności związana jest z zagwarantowaniem ochrony konstytucyjnych wolności, praw i zakresu obowiązków człowieka i obywatela. Podział władzy i równoważenie się poszczególnych władz działa w mechanizmie prawa w przypadku samodzielnego, zgodnego z Konstytucją i jego wartościami wykonywania kompetencji i zadań publicznych przez organy władzy publicznej. Żaden z organów nie powinien być w ramach swojej aktywności przypisanej państwu i suwerenowi podporządkowany władzy partii politycznych. Zasada pluralizmu politycznego ma za zadanie umożliwienie obywatelom zrzeszanie się celem artykułowania swoich oczekiwań i dążeń politycznych. Jednak w pewien sposób nieuniknione, m.in. wskutek systemu wyborczego, potencjalne przełożenie na ludzi animujących funkcje organów władzy publicznej ich poglądów politycznych powinno być zdystansowane, a nawet wyeliminowane treścią obowiąującego prawa i zasadami demokratycznego państwa prawnego. W tym przypadku państwo, stanowiące prawną formę organizacji realizacji woli suwerena, stanowi dobro wspólne wszystkich obywateli. Władza zwierzchnia należy do Narodu, a nie do większości rządzącej. Demokracja, $\mathrm{w}$ tym przede wszystkim przedstawicielska, powinna w ujęciu teoretycznym, prawnym i rzeczywistym zapewniać poszanowanie praw mniejszości przez większość. Skrajne społeczne i polityczne zjawiska, takie jak populizm; przejaskrawiona, przeformalizowana, pozbawiona adekwatności i zharmonizowanych aspektów materialnych poprawność polityczna; a także posiadajacy te same atrybuty tzw. dyktat mniejszości lub odpowiednio większości - są w swojej istocie negatywnymi aksjologicznie potencjalnymi formami refleksowania, czy nawet ingerencji, polityki w porządek konstytucyjny państwa. W tym ujęciu także negatywnie trzeba oceniać zjawisko instrumentalizacji prawa, które powinno obiektywnie służyć ponadczasowym zobiektywizowanym wartościom zakodowanym w Konstytucji, a nie chwilowo aktualnym interesom partii rządzącej czy jakiejkolwiek innej.

Odchodząc od wąskiego rozumienia władzy wykonawczej i nawiązując odpowiednio w tym względzie do bytu prawnego całej administracji publicznej, trzeba stwierdzić, że zwierzchnia władza narodu sięga zarówno spraw administracji naczelnej, centralnej, jak i terenowej (rządowej i samorządowej). W odniesieniu do administracji terenowej trzeba wskazać, że w jej ustroju gwarantowane sa zarówno potrzeby realizacji celów i zadań publicznych z pespektywy przede wszystkim interesu państwa, czego przejawem jest scentralizowana terenowa administracja rządowa podporządkowana hierarchicznie Radzie Ministrów, jak i odpowiednio w pierwszej kolejności

18 Na temat rządzenia zob. Izdebski, Kulesza (1998): 120. 
interesy wspólnot terytorialnych, czego przykładem jest byt prawny podmiotów (jednostek) samorządu terytorialnego. W demokratycznym państwie prawnym suweren wydziela, zgodnie z zasadą pomocniczości, w obrębie władzy wykonawczej przynależnej organom administracji publicznej sferę zadań i spraw lokalnych, ponadlokalnych, regionalnych związanych z zaspokajaniem zbiorowych potrzeb i użytecznościa publiczną i przekazuje administrowanie tymi sprawami wspólnotom terytorialnym wyposażonym przez państwo w kompetencje do administrowania nimi. Co szczególnie ważne, administrowanie dzięki prawnemu upodmiotowieniu wspólnot odbywa się nie tylko w drodze pośredniej przy pomocy organów wspólnot, ale także przy wykorzystaniu form demokracji bezpośredniej w zakresie administrowania lokalnymi, ponadlokalnymi i sprawami z zakresu administracji publicznej. Zgodnie z treścią art. 11 ust. 1 ustawy z 8 marca 1990 r. o samorządzie gminnym mieszkańcy gminy podejmują rozstrzygnięcia w głosowaniu powszechnym (poprzez wybory i referendum) lub za pośrednictwem organów gminy. Prawne znaczenie instytucji samorządu terytorialnego dla demokratycznego państwa prawnego polega na tym, że pozwala uruchomić atrybuty demokracji bezpośredniej i pośredniej właściwe dla związku publicznoprawnego w zakresie wykonywania terytorialnej lokalnej administracji publicznej. W związku z tym jednostka, mieszkaniec, zgodnie z zasadą pomocniczości, ma bezpośredni lub pośredni wpływ - za pośrednictwem wybranych przez siebie organów związku publicznoprawnego - na sposób administrowania sprawami publicznymi terytorialnymi. W ten sposób zwierzchnia władza Narodu uruchamiana jest w zakresie administracji publicznej sprawami terytorialnymi przez upodmiotowione prawnie na wzór związków publicznoprawnych innych niż państwo wspólnoty samorządowe.

Wspólnoty samorządowe są wyodrębniane $\mathrm{z}$ uwagi na kryterium terytorium. Ustawy ustrojowe akcentuja, że regulowane nimi jednostki samorządu terytorialnego to wspólnoty samorządowe wraz z terytorium, na które rozciąga się ich władztwo administracyjne. Zgodnie z art. 1 ust. 2 ustawy o samorzadzie gminnym ilekroć w ustawie jest mowa o gminie, należy przez to rozumieć wspólnotę samorządową oraz odpowiednie terytorium. Z uwagi na fakt, że to terytorium stanowi kryterium wyodrębnienia wspólnoty samorządowej i jednocześnie mapuje zakres władztwa terytorialnego, pozytywnie należy ocenić kierunek regulacji ustrojowych, które doprecyzowują kwestie zmian terytorialnych gmin, nadawania statusu miasta, ustalania i zmiany nazw gmin. Istotne jest, że w sprawie utworzenia, połączenia, podziału i zniesienia gminy oraz ustalenia granic gminy może być przeprowadzone referendum lokalne z inicjatywy mieszkańców (art. 4c ustawy o samorządzie gminnym). Ważne jest także uregulowanie następstwa prawnego gminy powstałej w wyniku połączenia gmin.

Nawiązując w tym miejscu do aksjologii samorządu terytorialnego, trzeba stwierdzić, że jako prawnie upodmiotowiona korporacyjnie związkowo wspólnota samorządowa stanowi on legitymizowaną przez suwerena (państwo/ ustrojodawcę w drodze demokracji przedstawicielskiej) względnie samodzielna formę sprawowania administracji publicznej zasadniczo w zadaniach i spra- 
wach lokalnych (terytorialnych) zarówno w interesie państwa, jaki i interesie lokalnym. Relacje tutaj wyglądają następująco: nie może być mowy o dobru państwa w zakresie administrowania sprawami publicznymi, jeżeli sprawy o charakterze terytorialnym związane z zaspokajaniem potrzeb wspólnot miałyby być bez uzasadnienia opartego na prawie podporządkowane bezwzględnie dobru państwa, dobru ogółu. W takim stopniu, w jakim to jest możliwe bez naruszenia dobra państwa i interesu ogółu, administrowanie sprawami publicznymi o charakterze lokalnym powinno być realizowane przez wspólnoty i podporządkowane dobru wspólnot terytorialnych. A zatem z dobrem państwa w sprawach z zakresu zadań administracji publicznej mamy do czynienia wtedy, kiedy w tym dobru mieści się odpowiednio dobro wspólnot samorządowych, definiowane przez nie zgodnie z porządkiem prawnym w ramach ich zadań i kompetencji przez organy tych wspólnot, a także w formie demokracji bezpośredniej.

Wspólnoty samorządowe są jako podmioty prawa publicznego jakościowo różne od suwerena Narodu, do którego należy władza zwierzchnia. Sa wyodrębniane z mocy ustawy, z uwagi na ustrój terenowy, dla celów administrowania sprawami lokalnymi, w związku z tym nie jest istotny pierwiastek obywatelstwa, a fakt stałego zamieszkania na danym terytorium. Podwójna legitymizacja bytu prawnego jednostek samorządu terytorialnego polega na tym, że zostały one uznane przez władzę zwierzchnia, ustrojodawcę, w związku z czym kreowane z mocy ustawy działają, opierając się na organach stanowiaccych, a w gminie i wykonawczych, pochodzacych z bezpośrednich wyborów lokalnych w zakresie władzy wykonawczej, zgodnie z metodą właściwą związkom publicznoprawnym (wspólnotom samorządowym) innym niż państwo. Podział władzy wykonawczej w szerokim tego znaczeniu za pośrednictwem rozdziału zadań publicznych na rzecz podmiotów scentralizowanych i zdecentralizowanych jest zróżnicowany aksjologicznie. Z jednej strony służy realizacji zadań własnych przez upodmiotowione prawnie wspólnoty, z drugiej - wskutek instytucji zadań zleconych z mocy ustawy i odpowiednio przejętych w drodze dobrowolnych porozumień wykorzystuje w terenie w imię realizacji interesu państwa zdolność administracyjna podmiotów samorządu terytorialnego. Jednocześnie z uwagi na możliwość przejmowania przez jednostki samorządu terytorialnego zadań publicznych $\mathrm{w}$ drodze dobrowolnie zawieranych porozumień, mamy do czynienia z dopuszczonym przez ustawy „wtórnym” funkcjonalnym podziałem zadań publicznych i związanych z nimi kompetencji w ramach porozumień stanowiących zarazem tzw. quasi-akty prawa miejscowego.

$\mathrm{Na}$ powyższe zjawiska nakłada się zjawisko redefiniowanej obecnie suwerenności państwa, co jest związane z procesem regionalizacji, europeizacji i globalizacji. Na status prawny jednostek samorządu terytorialnego wpływa istotnie członkowsko RP w Unii Europejskiej, a także odpowiednio wcześniejsze w Radzie Europy. Zgodnie z art. 90 ust. 1 Konstytucji Rzeczpospolita Polska może na podstawie umowy międzynarodowej przekazać organizacji międzynarodowej lub organowi międzynarodowemu kompetencje organów władzy państwowej w niektórych sprawach. W konsekwencji organy jednostek samo- 
rządu terytorialnego wykonują normy prawa europejskiego, a dorobek prawny Unii Europejskiej i Rady Europy przewiduje różne możliwości i ramy ponadgranicznej współpracy władz regionalnych i lokalnych ${ }^{19}$.

\section{PODMIOTOWE I PRZEDMIOTOWE ASPEKTY PODZIAŁU WLADZY WYKONAWCZEJ}

Z punktu widzenia konstytucyjnej zasady podziału władzy trzeba zaznaczyć, że zasada ta przewiduje nie tylko podział władzy zwierzchniej Narodu na trzy obszary aktywności państwa, w związku z czym Konstytucja wyodrębnia władzę ustawodawczą, wykonawczą i sądownicza, ale - jak to już było sygnalizowane - zgodnie z wymogiem równoważenia tych władz każda z nich podlega określonym podziałom wewnętrznym, co jest także niezwykle istotne dla optymalnej realizacji zasady podziału władzy. Z treści art. 15 w zw. z art. 10 Konstytucji wynika, że władza publiczna, w wykonywaniu której uczestniczy samorząd terytorialny, stanowi odpowiedni zakres władzy wykonawczej, na którą składa się przysługująca samorządowi terytorialnemu w ramach ustaw istotna część zadań publicznych wykonywana przez niego w drodze własnych kompetencji w imieniu własnym i na własną odpowiedzialność.

W tym miejscu trzeba zauważyć, że do tej pory w piśmiennictwie były przede wszystkim podnoszone aspekty decentralizacji władzy wykonawczej, m.in. przez instytucję samorządu terytorialnego. W moim przekonaniu na samorząd terytorialny trzeba także spojrzeć bardziej abstrakcyjnie jako na podmiotowy czynnik, przy pomocy którego ustrojodawca dokonuje podziału podmiotowego i przedmiotowego i funkcjonalnego (kompetencyjnego) w obrębie samej szeroko rozumianej władzy wykonawczej. Decentralizacja jest w tym przypadku zarazem swoistą formą podziału władzy wykonawczej, a zasada pomocniczości stanowi materialnoprawne kierunkowe kryterium realizowania zasady decentralizacji w obrębie władzy wykonawczej. W myśl art. 15 Konstytucji: „1. Ustrój terytorialny Rzeczypospolitej Polskiej zapewnia decentralizację władzy publicznej. 2. Zasadniczy podział terytorialny państwa uwzględniający więzi społeczne, gospodarcze lub kulturowe i zapewniajacy jednostkom terytorialnym zdolność wykonywania zadań publicznych określa ustawa”. Na ustrój terytorialny składa się, jak podnoszą konstytucjonaliści, „struktura, organizacja, zadania i kompetencje organów władz publicznych działających w jednostkach podziału terytorialnego państwa, a zatem na niższym szczeblu niż poziom władz ogólnokrajowych" 20 . Zatem proces decentralizacji wykonywania zadań publicznych przez względnie samodzielne jednostki samorządu terytorialnego spełnia zarazem wymo-

19 Zob. m.in. rozporządzenie (WE) nr 1082/2006 Parlamentu Europejskiego i Rady z 5 lipca 2006 r. w sprawie europejskiego ugrupowania współpracy terytorialnej (EUWT), Dz. Urz. UE L 210 z 31 lipca 2006 r.: 19, ze zm., a także ustawa z 7 listopada 2008 r. o europejskim ugrupowaniu współpracy terytorialnej, Dz. U. 2008, Nr 218, poz. 1390.

20 Winczorek (2000): 26. 
gi dzielenia zadań publicznych i przynależnych im kompetencji pomiędzy administracją rządowa naczelna, centralna, terenowa, tym samym spełnia także wymogi realizacji zasady podziału władzy.

Trzeba w tym miejscu zauważyć, że podmioty samorządu terytorialnego stanowia podmioty administracji publicznej charakteryzujące się dużym stopniem samoregulacji przy wykonywaniu zadań publicznych. Ta zdolność do samoregulacji spraw ustrojowych i organizacyjnych przekłada się na potencjalną optymalizację wykonywania zadań publicznych wynikającą z możliwości dopasowania warunków ich realizacji do wymogów rzeczywistości. Zarazem wskazywana samoregulacja determinuje dopuszczona prawem organizacyjna specyfikę, szczególność wykonywania zadań publicznych ustrojowo przynależnych danemu podmiotowi samorządu terytorialnego. Zakres działania i właściwość rzeczowa danej jednostki samorządu terytorialnego zależy także od zawartych przez nią porozumień i związków. Mieści to w sobie zarówno aspekty pozytywne, jak i negatywne w przypadku niedopracowania przejrzystości i dostępności prawnych mechanizmów informacyjnych o sposobie wykonywania zadań publicznych. Wyrazem tej samoregulacji są: samodzielność statutowa, samodzielność zadaniowa, samodzielność organizacyjna decydująca o sposobie wykonywania zadań publicznych, która w tym celu może wykorzystywać instytucje porozumień zarówno z organami administracji rządowej, jak i z innymi podmiotami samorządu terytorialnego, związków w tym gminno-powiatowych i ugrupowań europejskich. Normatywnie samorządy terytorialne maja konstytucyjnie zagwarantowaną samodzielność finansową i dochodowa, jednak w tym zakresie nauka, praktyka i rzeczywistość wskazują na względny brak skuteczności przyjętych rozwiązań prawnych i ich osłabianie w czasie przez regulacje prawne niwelujace zdolność finansową i dochodową jednostek samorzadu terytorialnego ${ }^{21}$.

Nie mniej istotny dla zasady podziału władzy jest mechanizm wzajemnego hamowania się władzy i organów jednostek samorządu terytorialnego. W tym obszarze pojawia się przestrzeń stosunków ustrojowo-organizacyjnych pomiędzy organami poszczególnych jednostek samorządu terytorialnego. Bezsprzecznie zawsze aktualnym podstawowym problemem w tym zakresie jest takie ich uregulowanie, aby organ stanowiący i kontrolny danej jednostki samorządu terytorialnego mógł sprawnie i skutecznie uruchomić odpowiedzialność polityczna przed wyborcami organu wykonawczego pochodzącego z wyborów bezpośrednich, z jednej strony nie obawiając się o swój byt prawny, a z drugiej - nie czynić z tej możliwości prawnej instrumentu politycznej rozgrywki z organem wykonawczym jednostki samorządu terytorialnego. Problemem organizacyjnym jest także kwestia wykonania postanowień organu stanowiącego jednostki, przy założeniu, że w obrocie prawnym istnieją organy wykonawcze, ale jednostek samorządu terytorialnego. Problemem aksjologicznym jest prawne zagwarantowanie zgodnego z wartościami demokratycznego państwa prawnego wykorzystania instytucji socjologicznej przywództwa jako refleksu władzy wójta, burmistrza, prezydenta miasta.

${ }^{21}$ Zob. na ten temat: Kornberger-Sokołowska (2020): 318-320; (2015): 191-195. 


\section{CZŁOWIEK WOBEC SAMORZĄDU TERYTORIALNEGO}

Godność człowieka stanowi fundamentalną wartość, której służy demokratyczne państwo prawne, a zatem i instytucja samorządu terytorialnego ${ }^{22}$. Podmiot samorządu terytorialnego znajduje upodmiotowienie dzięki swoistemu utożsamieniu go z powstającą bezpośrednio z mocy ustawy wspólnotą samorządową i wyposażeniu go w osobowość prawną. Z kolei wspólnota samorządowa znajduje upodmiotowienie w człowieku, w mieszkańcu. Bez człowieka nie ma wspólnoty samorządowej. To wartości zawarte w człowieku pozwalają mówić o inteligentnej gminie, inteligentnym mieście czy metropoliii ${ }^{23} \mathrm{Co}$ prawda dobro wspólnoty jest czymś więcej niż sumą tego, co stanowi dobro dla człowieka z jego perspektywy indywidualnej, jednak w założeniu aksjologicznym dobro wspólnoty samorządowej powinno uwzględniać dobro mieszkańca/ człowieka jako członka tej wspólnoty. Z perspektywy państwa i samorządu terytorialnego istotne jest umacnianie w człowieku postaw obywatelskich i patriotycznych, czym zajmuje się ustawowo szczególnie samorząd województwa przy jednoczesnym propagowaniu i umacnianiu przez gminę idei samorządności i więzi międzypokoleniowych.

Podstawowym problemem $\mathrm{w}$ zakresie ustroju samorządu terytorialnego jest stałe niwelowanie alienacji organów samorządu terytorialnego od oczekiwań wspólnoty samorządowej i mieszkańców, dystansu strukturalnego pomiędzy człowiekiem, mieszkańcem a organami samorządu terytorialnego, a także zmotywowanie go do korzystania z mechanizmów demokracji bezpośredniej przy zarządzaniu sprawami publicznymi o charakterze lokalnym. Bezsprzecznie służy temu obywatelska inicjatywa uchwałodawcza, instytucja referendum i konsultacji, budżet obywatelski, skarga na uchwały i zarządzenia organów samorządowych w sprawach z zakresu administracji publicznej. W tym zakresie istotne jest także optymalne wykorzystanie zjawiska dekoncentracji samorządu terytorialnego przez odpowiednią organizację funkcjonowania jednostek pomocniczych, a także wprowadzenie instrumentów prawnych pozwalających na wykorzystanie form aktywności człowieka właściwych społeczeństwu obywatelskiemu w ramach ustawy z 24 kwietnia 2003 r. o działalności pożytku publicznego i o wolontariacie ${ }^{24}$. W konsekwencji samorząd terytorialny, jego ustrój i organizacja przyczyniają się do wykonywania zadań publicznych przez organizacje społeczne i użyteczności publicznej.

\section{PODSUMOWANIE}

Prawo i nauka z pojęciem samorządu terytorialnego łączą zasadę podziału władzy publicznej, zasadę państwa jednolitego, zasadę decentralizacji, pomoc-

${ }^{22} \mathrm{Z}$ perspektywy materialnego prawa administracyjnego zob. Bąkowski (2007): 84. Na temat godności człowieka zob. Niżnik-Mucha (2014): 47-60.

${ }^{23}$ Zob. Chrisidu-Budnik (2019): 104-108.

${ }^{24}$ Zob. m.in. art. 5, art. 5a, art. 12, art. 13, art. 16, art. 19b ustawy z 24 kwietnia 2003 r. o działalności pożytku publicznego i o wolontariacie, t.jedn.: Dz. U. 2020, poz. 1057. 
niczości, dekoncentracji, zespolenia, ale w przypadku podziału władzy przede wszystkim koncentrują się na tym, że działalność samorządu terytorialnego mieści się w zdecentralizowanym wykonywaniu władzy publicznej odpowiadającej władzy wykonawczej w szerszym tego słowa znaczeniu. W pewien sposób wymknęło się tutaj z pola widzenia badanie korelacji na linii administracja rządowa - samorząd, organy wyborcze - samorząd pod kątem podziału władzy wykonawczej (zadań publicznych i kompetencji), w tym wzajemnego hamowania się i współdziałania władzy administracji rządowej, organów wyborczych i władzy samorządowej, a także wielopoziomowego zarządzania w UE i koegzystencji decentralizacji z sieciowością struktur.

$\mathrm{W}$ mojej ocenie proces równoważenia, współdziałania i hamowania się władzy administracji rządowej i samorządu terytorialnego wychodzi w pewien sposób poza ramy nadzoru ograniczonego (weryfikacyjnego). Nadzór ten jest korelatem decentralizacji. Cechy podziału władzy ma już sam dokonany prawem podział zadań publicznych, kompetencji i odpowiedzialności. Powstaje zatem problem zasad i kryterium rozdziału tych zadań publicznych w obrębie administracji publicznej ${ }^{25}$. Już przez sam taki podział dochodzi do równoważenia i hamowania się władz, przy czym dla równoważenia się wewnętrznego podziału władzy niezbędna jest możliwość wzajemnego różnorodnego odziaływania na siebie, którego granica zasadniczo jest nadzór weryfikacyjny. Cechy podziału władzy ma jednak także m.in. wpływ administracji rządowej na uchwalanie statutu, kształtowanie granic jednostek samorządu terytorialnego, tworzenia przez nie związków i stowarzyszeń, w tym metropolii ${ }^{26}$, wykonywania aktów polityki administracyjnej ${ }^{27}$. Z tego punktu widzenia trzeba poddać refleksji instytucje i pojęcia związane z aparatura pojęciową służąca do charakteryzowania samorządu terytorialnego i administracji rządowej, a także organów wyborczych. Problem wzajemnego hamowania się władz jest istotny w przypadku zadań z zakresu administracji rządowej wykonywanych przez samorząd terytorialny, a także w zakresie aktów planowania i polityki administracyjnej. Na te instytucje trzeba patrzeć nie tylko z perspektywy wykorzystania możliwości administracyjnych samorządu terytorialnego do realizacji zadań o charakterze ogólnopaństwowym, ale także w konwencji podziału władzy wykonawczej.

Iwona Niżnik-Dobosz

Uniwersytet Jagiellonski

iwona.niznik-dobosz@uj.edu.pl

https://orcid.org/0000-0003-1108-4548

${ }^{25} \mathrm{Na}$ ten temat w nawiązaniu do pojęcia interesu lokalnego zob. Górski, Barczak (2015): $107-108$.

${ }^{26}$ Zob. m.in. art. 4 i art. 5 ustawy z 9 marca 2017 r. o związku metropolitalnym w województwie śląskim, Dz. U. 2017, poz. 730.

${ }^{27}$ Zob. art. 35 ust. 3 ustawy z 20 kwietnia 2004 r. o Narodowym Planie Rozwoju, t.jedn.: Dz. U. 2019, poz. 1465. 
Bigo, T. (1928). Zwiąki publiczno-prawne w świetle ustawodawstwa Polskiego. I Seria Klasyki Samorządowej (reprinty). Warszawa (reprint 1990).

Bigo, T. (1932). Prawo administracyjne. Część ogólna (stenogram wykładów uniwersyteckich). Lwów.

Bąkowski, T. (2007). Administracyjnoprawna sytuacja jednostki w świetle zasady pomocniczości. Warszawa.

Błaś, A., Boć, J. (red.), Jeżewski, J. (2003). Administracja publiczna. Wrocław.

Chrisidu-Budnik, A. (2019). Od biurokracji do New Public Governance. Perspektywa izomorfizmu instytucjonalnego. Wrocław.

Czarny, P., Florczak-Wątor, M., Naleziński, B., Radziewicz, P., Tuleja, P. (red.) (2019). Konstytucja Rzeczypospolitej Polskiej. Komentarz. Warszawa.

Dolnicki, B. (1994). Modele samorządu terytorialnego w Europie i w Polsce. Katowice.

Dolnicki, B. (2005). Ustrój samorządu terytorialnego w świetle standardów europejskich, [w:] Z. Janku, Z. Leoński, M. Szewczyk, M. Waligórski, K. Wojtczak (red.), Europeizacja polskiego prawa administracyjnego. Wrocław: 42-52.

Górski, M. Barczak, A. (2015). Art. 4 ust. 3 Europejskiej Karty Samorządu Terytorialnego jako inspiracja do przeglądu układu kompetencji między administracją samorządową i administracją rządową w zakresie ochrony środowiska, [w:] M. Ofiarska (red.), Europejska Karta Samorządu Terytorialnego a prawo samorządu terytorialnego. Szczecin: 95-109.

Grzeszczak, R., Zawada-Szczerba, A. (red.) (2016). Prawo administracyjne Unii Europejskiej. Warszawa.

Grzeszczak, R. (2016). Koncepcja wielopoziomowego rządzenia, [w:] R. Grzeszczak, A. Szczerba-Zawada (red.), Prawo administracyjne Unii Europejskiej. Warszawa: 197-203.

Izdebski, H., Kulesza, M. (1998). Administracja publiczna. Zagadnienia ogólne. Warszawa.

Jakubek-Lalik, J. (2016). Krajowa administracja publiczna w warunkach członkostwa w Unii Europejskiej, [w:] R. Grzeszczak, A. Szczerba-Zawada (red.), Prawo administracyjne Unii Europejskiej. Warszawa: 71-83.

Janku, Z., Leoński, Z., Szewczyk, M., Waligórski, M., Wojtczak, K. (red.) (2005). Europeizacja polskiego prawa administracyjnego. Wrocław.

Kasznica, S. (1946). Polskie prawo administracyjne. Poznań.

Kiczka, K. (2013). Krajowy organ administracji publicznej w prawie unijnym. Wrocław.

Kornberger-Sokołowska, E. (2015). Zasada adekwatności środków do zadań - aktualne problemy, [w:] M. Ofiarska, Europejska Karta Samorządu Terytorialnego a prawo samorządu terytorialnego. Szczecin: 183-195.

Kornberger-Sokołowska, E. (2020). O potrzebie instytucjonalnego wzmocnienia idei samorządności - aspekt finansowo-prawny. Samorząd Terytorialny 4(352): 9-16.

Małajny, R.M. (2001). Trzy teorie podzielonej władzy. Warszawa.

Małajny, R.M. (2009). Zasada podziału władzy a system rządów parlamentarnych. Państwo i Prawo 64(12): 16-30.

Miemiec, W., Pest, P. (2015). „Janosikowe” a standardy dotyczące procedur wyrównawczych w Europejskiej Karcie Samorządu Terytorialnego, [w:] M. Ofiarska, Europejska Karta Samorządu Terytorialnego a prawo samorządu terytorialnego. Szczecin: 289-321.

Niżnik-Mucha, A. (2014). Zakaz naruszania istoty konstytucyjnych wolności i praw w Konstytucji Rzeczypospolitej Polskiej. Warszawa.

Ofiarska, M. (red.) (2015). Europejska Karta Samorządu terytorialnego a prawo samorządu terytorialnego. Szczecin.

Panejko, J. (1926). Geneza i podstawy samorządu europejskiego. Paryż. I Seria Klasyki Samorządowej (reprinty). Warszawa (reprint 1990).

Pułło, A. (1993). Podział władzy. Aktualne problemy w doktrynie, prawie i współczesnej dyskusji konstytucyjnej w Polsce. Przegląd Sejmowy 3(3): 9-26.

Skrzydło-Niżnik, I. (2000). Prawne i prawnicze koncepcje władzy wykonawczej na tle ostatnich 10 lat przemian ustrojowych w Polsce. Samorząd Terytorialny 10(1/2): 73-81.

Skrzydło-Niżnik, I. (2007). Model ustroju samorządu terytorialnego w Polsce na tle zagadnień ustrojowego prawa administracyjnego. Kraków.

Supernat, J. (2013). Administracja Unii Europejskiej. Zagadnienia wybrane. Wrocław. 
Taras, W. (2005), Demokracja bezpośrednia na tle reform samorządu terytorialnego, [w:] Z. Janku, Z. Leoński, M. Szewczyk, M. Waligórski, K. Wojtczak (red.). Europeizacja polskiego prawa administracyjnego. Wrocław: 215-224.

Winczorek, P. (2000). Komentarz do Konstytucji RP z 2 kwietnia 1997 r. Warszawa.

\section{LOCAL SELF-GOVERNMENT IN VIEW OF THE PRINCIPLE OF THE SEPARATION OF POWERS}

\section{Sum mary}

The text presents the view that the vertical division within the executive power, determined by the principle of decentralisation, is legally instrumental in the face of the fundamental horizontal division of power (resulting from the principle of power sharing) and is not independent and separate from the principle of power sharing. It is worth defining the place of local self-government from the perspective of the division of the executive power, and in reference to the principle of power sharing, because of the importance that these arrangements may have for the concept of multi-level governance in the European Union. The system of the bodies and institutions of the European Union is not based on the principle of the separation of powers, but on institutional division and the vertical and horizontal opening of the legal systems of the Member States to the European legal order. At the same time, the above-mentioned multi-level governance is visible in the creation and implementation of European law. The principle of the separation of powers is, however, properly embedded in this multi-level governance at the level of national law, and within this local self-government is located accordingly.

Keywords: principle of the self-division of powers; executive power; local government; decentralization principle 